tion was due to the rust, the uredo stage of which was just beginning to make its appearance. The specimens were put away and were not again examined until a short time ago when it was decided to make a proper identification of them. When they were taken it was our intention to revisit the fields and collect the teleuto stage, but owing to press of other work this was not done. When a reexamination of the material was made we found it impossible to determine the species and a sending was therefore made to Mrs. Flora W. Patterson, mycologist, U. S. Department of Agriculture, Washington, D. C. The tentative opinion of the writer, that the rust in question was none other than Puccinia glumarum Eriks. and Henn., has been confirmed both by Mrs. Patterson and the pathologists in the Cerealist's Office at Washington.

Just two days previous to our finding this rust, Dr. F. Kolpin Ravn, of Copenhagen, Denmark, Mr. A. G. Johnson, of the University of Wisconsin, and Dr. H. B. Humphrey, of the U. S. Department of Agriculture, visited the Salt Lake Valley and were undoubtedly on the lookout for this rust which was seen for the first time in this country at Sacaton, Arizona. ${ }^{1}$ The writer had the pleasure of entertaining these gentlemen during this visit, making with them a short automobile tour about the valley in the interest of cereal diseases.

The rust infection due to Puccinia glumarum, as noted in the Salt Lake Valley, is undoubtedly of greater economic importance than had hitherto been supposed. It is not known to what extent the wheat crop was injured, but it is the writer's opinion that the loss over a considerable area must have been quite heary if the extent of the infection could be taken as a criterion. During the present season careful notes will be made on the occurrence, distribution and effect of this rust on wheat in the Salt Lake Valley and adjacent districts.

Dept. of Agri. Investigations,

$$
\text { P. J. O'GARA }
$$

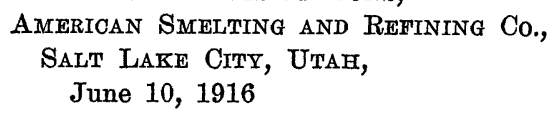

1 ScIENCE, N. S., Vol. XLII., No. 1071, p. 58.

\section{IS INHERITANCE MODIFIED BY ACQUIRED CHARACTERS?}

IN the American Naturalist for August, 1916, I find an interesting article by Dr. C. B. Davenport, on "The Form of Evolutionary Theory that Research Seems to Favor." The general result of his investigation is "that the course of evolution is chiefly determined by internal changes," that is, by genetic changes. He, however, reminds us that "there is some evidence ... that the germ plasm is not beyond the reach of modifying agents. At least we must continue experimental efforts in that direction."

The question which I wish to raise is whether attention has been given to the book by Walter Kidd, entitled "The Direction of Hair in Animals and Man," published by Adam and Charles Black, London, 1903. On pages 76 and 81 will be found pictures showing the difference in the arrangement of hair on the head of the chimpanzee, and that found on the heads of many young human subjects, who seem to have inherited some of the new arrangements through the influence of the artificial parting of the hair, practised by their ancestors for several generations. If these pictures correctly represent inherited conditions, it seems impossible to attribute them to spontaneous variations, uninfluenced by habit, and preserved simply because they gave their subjects superior power in the struggle for life, or because of any other form of selection.

For several years failing eyesight has restricted, not only my own investigations, but my knowledge of what others have accomplished; and I shall be thankful for any information as to whether these points have been discussed in the American Naturalist, or in any of our scientific journals.

HoNoLuLU, T. H.

JoHN T. GuLICK

\section{TUMORS IN PLANTS}

AT last I have succeeded in producing small tumors in plants without the use of the crown gall organism (Bacterium tumefaciens), i. e., simply by means of substances which are by- 